\title{
sciendo
}

\section{Knowledge sharing and innovation capability at both individual and organizational levels: An empirical study from Vietnam's telecommunication companies}

\author{
Tuan Phong NHAM \\ VNU University of Economics and Business, Hanoi City, Vietnam \\ tuannp@vnu.edu.vn \\ Tuyet-Mai NGUYEN \\ Department of Marketing, Griffith University, Brisbane, Australia and Department of Information \\ and E-commerce, Thuongmai University, Hanoi, Vietnam \\ maidhtm@tmu.edu.vn \\ Nam Hoai TRAN \\ Department of Economic Information Systems and Electronic Commerce, Thuongmai \\ University, Hanoi. \\ namth@tmu.edu.vn \\ Hao Anh NGUYEN \\ Department of Business Administration, Graduate School of International Social Sciences, \\ Yokohama National University \\ nguyenanhhao040294@gmail.com
}

\begin{abstract}
This paper aims at investigating the relationship between knowledge sharing activities and innovation capability at both individual and organizational levels. By reviewing extensive literature, a conceptual framework is built with integrating three factors: knowledge sharing, individual innovation capability and firm innovation capability. This study applies structural equation modeling (SEM) to analyze the data collected from 392 employees working at major Vietnam's telecommunication companies. Empirical results show that knowledge sharing including knowledge donating, knowledge collecting play an important role in improving individual innovation capability. There is no direct link between knowledge collecting and organizational innovation capability, while knowledge donating has direct positive impact on product and managerial innovation. Furthermore, the individual innovation capability acts as a mediating variable between knowledge sharing practices and firm innovation capability. Implications for academics and practitioners are provided in this study.
\end{abstract}

Keywords: knowledge sharing, knowledge donating, knowledge collecting, firm innovation capability, individual innovation capability.

Please cite the article as follows: Nham, T.P., Tran, H.N., and Nguyen, A.H. (2020), "Knowledge sharing and innovation capability at both individual and organizational levels: An empirical study from Vietnam's telecommunication companies", Management \& Marketing. Challenges for the Knowledge Society, Vol. 15, No. 2, pp. 275-301. DOI: 10.2478/mmcks-2020-0017. 


\section{Introduction}

In the global and competitive market today, organizations always try to utilize their resources to be productive, effective and gaining competitive advantage over rivals. Besides, due to the unpredictable technology change every day that leads to unexpected demand of customers, organizations regardless of which industry they are operating in need to be responsive to the change in order to meet customers' requirement. To do that, innovation plays an important role that brings organization strategic advantages through quality improvement, new product and services development, cost reduction as well as differentiation (Yeşil et al., 2013). Applying effective innovation in organization allow the firm to achieve sustainable growth (Göğüş et al., 2013). Furthermore, firms all over the world are converging into same level of many aspects such as operations, marketing, human resources management, organizations are trying to build strong innovation capability because it is difficult for competitors to imitate and it is one of key factors that drive firm performance (Harrison \& Samaon, 2002). Therefore, many researchers have paid attention to find out which factors to enable innovation capability of employees as well as organization as a whole.

Telecommunication industry in Vietnam has been experiencing a long time of saturation. Over the past ten years, revenue of telecom industry is still growing because number of subscribers increase. However, higher number of emerging local telecom businesses are driving market competition. The competition among telecoms companies is no longer over tariffs matter but it is about creativity to meet customers' changing requirements. Several Vietnamese telecom providers are acting to tackle this issue. Most recently, Viettel Group - one of Vietnam's top telecom revealed that the company is investing on $5 \mathrm{G}$ chip and compatible devices using that chip, so that customers can enjoy better high-speed mobile services (Onishi, 2019). This project is a big challenge since it requires huge cost and time of development, as well as in-depth technical knowledge that Vietnamese companies are lacking. As a result,, Vietnamese telecom companies are seeking collaboration with foreign companies, to acquire necessary knowledge and technology, for example cooperation between Vinaphone and Nokia, MobiFone and Samsung Electronics recently (Onishi, 2019).

Knowledge management and innovation were found to be closely related (Plessis, 2007). Knowledge management includes various aspects such as knowledge life cycle, knowledge capture, knowledge development, knowledge sharing, and knowledge utilization (Liao et al., 2007). Among these aspects, knowledge sharing is considered major focus by organization to foster knowledge exchange and creation among employees within an organization. Many studies (Rahab et al., 2011; Lin, 2007; Tassabehji et al., 2019) showed that firm innovation capability can be improved through knowledge sharing process. Practically, recognizing the need of providing innovative products to customers, VNPT - a key telecommunication and IT enterprise have opened R\&D center where everyone including employees, external partners can come, connect and share their ideas to develop new products and services (VNPT, 2017). This example shows the importance of knowledge sharing on innovation, emphasizing that innovation of a company significantly relies on knowledge sources from its employees, partners or customers.

Many existing literatures focused on finding out knowledge sharing enablers including individual, organizational and technological factors, and how knowledge sharing affects firm innovation capability. However, there are limited studies that pay attention on innovation capability at both individual and organizational level, while employees' innovation capability should be original source of organizational innovation 
capability. "How individual innovation capability mediates the relationship between knowledge sharing and organizational innovation capability?" Addressing that research question would shed a light on the mechanism of how knowledge management lead to creativity in organizations, as well as provide implications to practitioners for better innovation management, raising the importance of individual creativity in contribution to organizational success, especially in telecommunication industry that is in need of innovation. Therefore, the purpose of this study is investigating relationship between knowledge sharing and innovation capabilities at individual as well as organizational levels from Vietnam's telecommunication companies.

\section{Literature review and hypothesis development Knowledge sharing}

At present, organizations focus more on knowledge sharing, which is an essential part of knowledge management (Liao et al., 2007). Knowledge sharing refers to the exchange of information among people, family or communities. In organizations, knowledge sharing occurs between individuals regarding ideas, suggestions, experience, expertise as well as skills (Bartol \& Srivastava, 2002). Knowledge sharing in an organization simply is the way organization make knowledge is available for employees (Ipe, 2003). Knowledge sharing as a process where individuals commonly exchange their implicit (tacit) and explicit knowledge to create new knowledge (Van Den Hooff \& De Ridder, 2004). According to Lin (2007), knowledge sharing behavior is divided into two sub-behaviors namely knowledge collecting and knowledge donating, which is utilized in this paper. These two "knowledge sharing" practices were derived from the idea that there are two parties involving in knowledge sharing process, namely "knowledge carrier" (or knowledge source) and "knowledge receiver" (Hendriks, 1999). Knowledge collecting refers to process of communicating and encouraging others to share their knowledge or intellectual capital, while knowledge donating is the behavior of transferring personal intellectual capital to others (Van Den Hooff \& De Ridder, 2004). In more details, both knowledge collecting and knowledge donating are practices implemented by employees, urging them to gain and transfer new information to make everyone's knowledge become more comprehensively. Knowledge sharing is more considered as voluntary act, making knowledge possessed by an individual are available for others to understand, absorb and utilize, finally lead to joint ownership of knowledge between senders and recipients (Ipe, 2003).

The importance of knowledge sharing has been emphasized in existing literature. Nowadays, companies are focusing on human capital and knowledgeable workforce to enhance organizational performance (Kuo et al., 2014). Knowledge sharing enables innovative behavior, which is employee's action to realize, promote and create new knowledge that are useful for organization (Akram et al., 2018). Externally, knowledge sharing with customers and suppliers can improve customer or supplier relationships, enhance new product development process, facilitate decision making, provide employees various types of knowledge that support employee's learning as well as organizational learning (Alavi et al., 2005; Andrews \& Delahaye, 2000). While knowledge donating helps to build organizational knowledge, generate ideas based on recognition of new business opportunities; knowledge collecting is important for project completion, as it involves internalization and socialization of knowledge (Lin, 2007; Hansen, 1999). Kamasak \& Bulutlar (2010) explored the relationship between knowledge collecting and knowledge donating on innovation, pointing out that knowledge collecting influence significantly to exploratory and exploitative innovation, whereas knowledge donating 
has effect only on exploitative innovation. Generally, collecting and integrating new knowledge will lead to innovativeness, but there is the need for further empirical studies that investigate the impact of knowledge sharing practices on employees' innovation and skills (Raykov, 2014). Existing literature that show the relationship between knowledge sharing and innovation are shown in Table 1.

\section{Innovation capability at individual and organizational level}

Innovation capability

Innovation is defined as process of creating new ideas, solutions that can meet new requirements or existing needs (Maryville, 1992). There are many ways to classify innovation: product/process, radical/incremental, technological/managerial or market pull/technology push (Verde et al., 2011). Innovation capabilities describe the firm's ability to accomplish high innovation performance on routine basis. According to Burgelman et al. (2004), innovation capabilities are comprehensive set of characteristics of an organization that support organizational innovation strategies. Using dynamic capabilities approach, Lawson \& Samson (2001) defines innovation capability as the capacity of transforming knowledge into new product, process to provide more benefit for organization and stakeholders (Lawson \& Samson, 2001). It shares the same view with Kogut \& Zander (1992), conceptualizing innovation capability as organizational ability to utilize and activate knowledge into the forms of products, services, processes and systems. In today's business environment, individual firms are distinguished with each other by building innovation capabilities that are difficult for others to imitate. It can be viewed as the way organization reconfigure its resources and capabilities to innovate (Aryanto et al., 2015). Recently, Wang \& Hu (2017) brought out the concept of collaborative innovation capability, which is known as the ability of involving key supply chain partners in innovation process. They pointed out that this type of innovation capability can affect positively to innovation performance, also significantly moderate the relationship between knowledge sharing and innovation (Wang \& $\mathrm{Hu}, 2017$ ). Innovation capability is viewed as one of the most important capabilities a firm can have, and it should be considered within an organization at both individual and organizational levels.

\section{Individual innovation capability}

Employee innovation capability refers to the ability as well as the tendency of employees to create new ideas and perform those ideas in order to obtain organizational objectives (Huhtala \& Parzefall, 2007). Innovativeness of employees was conceptualized as the degree an employee adopts or is willing to adopt something new (Hurt et al., 1977). It can also be viewed as employees' new perspectives about issues that arise, willingness to take risk and tolerance for ambiguity (Saunila \& Ukko, 2014). The importance of employee's initiatives in knowledge creation was early highlighted by Nonaka \& Takeuchi (1995), arguing that knowledge is created through multi-level employee interactions. Therefore, organizations cannot gain new knowledge, or at least, knowledge will have little impact on organizational effectiveness unless the knowledge are shared and understood among individuals and groups. Furthermore, since employees are critical sources of knowledge for organization, the organization is likely to lose the knowledge if there is no knowledge sharing, or when employees leave (Ipe, 2003). Davenport \& Prusak (1999) defined knowledge as personal, so that organization will only effectively manage knowledge resources when employees contribute knowledge to the firm. Literature have emphasized the importance of organizational support (ex. providing guidelines, set of practices to support continual improvement) to 
trigger individual innovation (Lotz, 2018). Hiltunen \& Henttonen (2016) argued that innovation can come from every employee in the company, even when it comes to shopfloor worker. However, employee's innovation ability is somewhat hidden, and their results indicated the importance of leadership support to improve employee-driven innovation.

\section{Organizational innovation capability}

The organizational innovation capability is the ability of an organization toward innovation such as fast respond to new information, quick problem-solving as well as to what extent the firm's culture is open to new ideas (Hurley \& Hult, 1998). This study categorizes organizational innovation into three types, based on Rajapathirana \& Hui (2018): Product/service innovation, Process innovation, and Managerial/organizational innovation. As such, product/service innovation is defined as the development of new product or service that meet customers' needs by adding technical specification, incorporated software. In response to dramatic change in the market, product innovation is crucial in carrying out new business opportunities to gain market share and expand company's business (Slater et al., 2014). Process innovation refers to improvements in the way a company manufactures and delivers its products/services (Canh et al., 2019). Therefore, process innovation is considered a novel change that customers may not directly pay for, such as new way of commercializing products/services and it helps to increase productivity, add more value to stakeholders (Rajapathirana \& Hui, 2018). However, process innovation, for example introducing new formalized process by adopting new technology, may has adverse effect if knowledge and experience are lack. It is suggested that process innovation should be implemented synchronously with managerial/organizational innovation (Letangule \& Letting, 2012). Managerial/organizational innovation is defined as new organizational method of managing, implementing business practices, internal as well as external relations (Rajapathirana \& Hui, 2018). Specifically, this type of innovation changes organizational systems by investing effort on improvement of administration, team collaboration, information sharing and learning. Process and managerial innovation are profound for service industry in terms of saving cost, increasing speed, especially in the telecommunication industry, where the product is infrequently changed unless there is big technological evolution.

Table 1. Recent studies on relationship between knowledge sharing and innovation capability

\begin{tabular}{|c|c|c|c|c|c|}
\hline Author & $\begin{array}{c}\text { Knowledge } \\
\text { sharing } \\
\text { operationalizat } \\
\text { ion }\end{array}$ & $\begin{array}{c}\text { Innovation } \\
\text { capability }\end{array}$ & $\begin{array}{l}\text { Sample \& } \\
\text { Industry }\end{array}$ & Methodology & Main findings \\
\hline $\begin{array}{l}\text { Tassab } \\
\text { ehji } \\
(2019)\end{array}$ & $\begin{array}{ll}\text { - } & \text { Knowledge } \\
\text { donation } \\
\text { - } \\
\text { Knowledge } \\
\text { collection }\end{array}$ & $\begin{array}{l}\text { Firm innovation } \\
\text { capability }\end{array}$ & $\begin{array}{l}\text { UK based } \\
\text { companies/creativ } \\
\text { e sector }\end{array}$ & $\begin{array}{c}\text { Two-stage } \\
\text { sequential } \\
\text { explanatory } \\
\text { mixed method } \\
\text { approach }\end{array}$ & $\begin{array}{l}\text { Importance of knowledge donation is } \\
\text { confirmed but there is limited } \\
\text { evidence of knowledge collection in } \\
\text { the knowledge sharing process }\end{array}$ \\
\hline $\begin{array}{l}\text { Akram } \\
\text { et al. } \\
(2018)\end{array}$ & $\begin{array}{l}\text { - } \text { Knowledge } \\
\text { donating } \\
\text { - } \text { Knowledge } \\
\text { collecting }\end{array}$ & $\begin{array}{l}\text { Employee } \\
\text { innovative work } \\
\text { behavior }\end{array}$ & $\begin{array}{c}115 \\
\text { employees/teleco } \\
\text { mmunication } \\
\text { sector }\end{array}$ & $\begin{array}{l}\text { Correlation, } \\
\text { multiple regression } \\
\text { analysis }\end{array}$ & $\begin{array}{l}\text { Knowledge donating and knowledge } \\
\text { collecting are positively and } \\
\text { significantly affect the innovative } \\
\text { work behavior }\end{array}$ \\
\hline
\end{tabular}




\begin{tabular}{|c|c|c|c|c|c|}
\hline $\begin{array}{l}\text { Chan et } \\
\text { al. } \\
(2017)\end{array}$ & $\begin{array}{l}\text { - Knowledge } \\
\text { donating } \\
\text { - Knowledge } \\
\text { collecting }\end{array}$ & $\begin{array}{ll}\text { - } & \text { Product } \\
& \text { innovation } \\
\text { - } & \text { Process } \\
& \text { innovation } \\
\text { - } & \text { Marketing } \\
\text { innovation } \\
\text { - } & \text { Strategic } \\
\text { innovation }\end{array}$ & $\begin{array}{c}62 \text { companies in } \\
\text { Taiwan/automobil } \\
\text { e }\end{array}$ & $\begin{array}{l}\text { Structural equation } \\
\text { modeling }\end{array}$ & $\begin{array}{l}\text { Knowledge collecting and knowledge } \\
\text { donating show positive effect on all } \\
\text { types of innovation capability }\end{array}$ \\
\hline $\begin{array}{l}\text { Podrug } \\
\text { et al. } \\
(2017)\end{array}$ & $\begin{array}{l}\text { - Knowledge } \\
\text { donating } \\
\text { - Knowledge } \\
\text { collecting }\end{array}$ & $\begin{array}{l}\text { Firm innovation } \\
\text { capability }\end{array}$ & $\begin{array}{c}196 \\
\text { employees/Inform } \\
\text { ation } \\
\text { communication } \\
\text { technology }\end{array}$ & $\begin{array}{l}\text { Structural equation } \\
\text { modeling }\end{array}$ & $\begin{array}{l}\text { Employee willingness to donate and } \\
\text { collect knowledge enable the firm to } \\
\text { improve } \\
\text { innovation capability }\end{array}$ \\
\hline $\begin{array}{l}\text { Yesil et } \\
\text { al. } \\
(2013)\end{array}$ & $\begin{array}{l}\text { - } \text { Knowledge } \\
\text { donating } \\
\text { - } \text { Knowledge } \\
\text { collecting }\end{array}$ & $\begin{array}{l}\text { Firm innovation } \\
\text { capability }\end{array}$ & $\begin{array}{l}51 \text { companies in } \\
\text { Turkey }\end{array}$ & $\begin{array}{l}\text { Partial Least } \\
\text { Squares, Structural } \\
\text { Equation Modeling }\end{array}$ & $\begin{array}{l}\text { Only knowledge donating has positive } \\
\text { influence on innovation capability }\end{array}$ \\
\hline $\begin{array}{l}\text { Wang } \\
\quad \& \\
\text { Wang } \\
(2012)\end{array}$ & $\begin{array}{l}\text { - } \text { Tacit } \\
\text { knowledge } \\
\text { sharing } \\
\text { - Explicit } \\
\text { knowledge } \\
\text { sharing }\end{array}$ & $\begin{array}{ll}\text { - Innovation } \\
\text { speed } \\
\text { - } \\
\text { Innovation } \\
\text { quality }\end{array}$ & $\begin{array}{c}89 \text { high-tech } \\
\text { firms/Information } \\
\text { \& communication, } \\
\text { electronics, } \\
\text { petrochemicals \& } \\
\text { plastics, chemicals, } \\
\text { medicals. }\end{array}$ & $\begin{array}{l}\text { Structural equation } \\
\text { modeling }\end{array}$ & $\begin{array}{l}\text { Explicit knowledge sharing has } \\
\text { positive impact on innovation speed } \\
\text { and quality. Meanwhile, tacit } \\
\text { knowledge sharing only has positive } \\
\text { effect on innovation quality. }\end{array}$ \\
\hline $\begin{array}{l}\text { Kamas } \\
\text { ak \& } \\
\text { Bulutla } \\
\quad r \\
(2010)\end{array}$ & $\begin{array}{ll}\text { - } & \text { Knowledge } \\
\text { collecting } \\
\text { - } & \text { Knowledge } \\
\text { donating } \\
\text { inside } \\
\text { - } \\
\text { Knowledge } \\
\text { donating } \\
\text { outside }\end{array}$ & $\begin{array}{ll}\text { - } & \text { Exploratory } \\
\text { innovation } \\
\text { - } \\
\text { Exploitative } \\
\text { innovation } \\
\text { - Ambidextrous } \\
\text { innovation }\end{array}$ & $\begin{array}{l}246 \text { middle and } \\
\text { top-level } \\
\text { managers/various } \\
\text { industries }\end{array}$ & $\begin{array}{l}\text { Exploratory factor } \\
\text { analysis, regression } \\
\text { analysis }\end{array}$ & $\begin{array}{l}\text { Knowledge collecting had a significant } \\
\text { effect on all types of } \\
\text { innovation and ambidexterity, } \\
\text { whereas knowledge donating did not } \\
\text { have any effect on exploratory } \\
\text { innovation }\end{array}$ \\
\hline $\begin{array}{l}\text { Lin } \\
(2007)\end{array}$ & 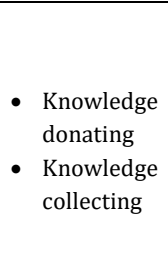 & $\begin{array}{l}\text { - Firm } \\
\text { innovation } \\
\text { capability }\end{array}$ & $\begin{array}{c}172 \\
\text { respondents/Man } \\
\text { ufacturing, } \\
\text { banking, } \\
\text { computers, } \\
\text { transportation, } \\
\text { retail, real estate, } \\
\text { health, utility }\end{array}$ & $\begin{array}{l}\text { Structural equation } \\
\text { modeling }\end{array}$ & $\begin{array}{l}\text { Employee willingness to both donate } \\
\text { and } \\
\text { collect knowledge enable the firm to } \\
\text { improve innovation capability. }\end{array}$ \\
\hline $\begin{array}{l}\text { Liao et } \\
\text { al. } \\
(2007)\end{array}$ & $\begin{array}{l}\text { - Knowledge } \\
\text { donating } \\
\text { - } \begin{array}{l}\text { Knowledge } \\
\text { collecting }\end{array}\end{array}$ & 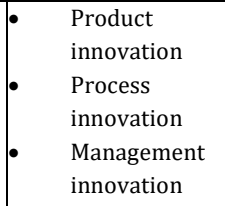 & $\begin{array}{l}\text { C355 } \\
\text { respondents/elect } \\
\text { ronic, financial } \\
\text { insurance and } \\
\text { medical industries. }\end{array}$ & $\begin{array}{l}\text { Structural equation } \\
\text { modeling }\end{array}$ & $\begin{array}{l}\text { Knowledge donating and knowledge } \\
\text { collecting have positive effect on } \\
\text { absorptive capacity, leading to higher } \\
\text { innovation capability. }\end{array}$ \\
\hline
\end{tabular}

Literature review shows that there have been a number of studies that investigate the relationship between knowledge sharing (consisting of "knowledge donating" and "knowledge collecting") in various industries. However, most of them have focused on either only relationship between knowledge sharing and individual innovation capability or between knowledge sharing and firm innovation capability. There are limited studies that integrate all those three factors. Moreover, research about innovation capability in telecommunication industry in developing economy such as Vietnam is generally lack. Furthermore, the effect of knowledge donating and knowledge collecting on firm innovation capability in existing literature is somewhat inconsistent. Therefore, this paper aims at integrating three factors knowledge sharing, individual innovation capability and organizational one into a comprehensive framework and empirically test the model by using data of Vietnam's telecommunication firms. 


\section{Relationship between knowledge sharing, individual innovation capability and firm innovation capability}

Knowledge sharing in organization frequently happens among individuals, which is through daily interaction and conversation between employees, so it affects individual innovation capability of employees. It is argued that knowledge sharing helps employees to think more critically as well as creatively (Aulawi et al., 2009; Ologbo, 2015). Holub (2003) indicated that if there are more knowledge sharing activities among employees, it is more likely for employees to attain ability to think and create new things. Anwahi (2012) concluded that effective practice of knowledge sharing helps to innovate employees. Ologbo (2015) hypothesized model of knowledge sharing and employees' innovation capability, then using regression analysis to test the model. The result showed that more involvement of employees in knowledge sharing process, employees have greater capabilities of generating new ideas. In addition, in research of Yu et al. (2013) about finance and insurance industry in Taiwan, knowledge sharing, and interactive activities were found to have positive effect on employees' innovative behavior and their ability to innovative. Hence, it can be hypothesized that:

H1: Knowledge sharing practices including knowledge collecting and knowledge donating have positive effects on individual innovation capability.

The contribution of knowledge sharing to firm innovation capabilities has been studied in many existing literature (Lin, 2007; Song et al, 2008; Podrug et al., 2017). It is strongly proved by previous researches that knowledge sharing activities can assist organizational innovation capability in problem solving and react faster to new information in the market. Liao et al. (2007) argued that with adequate absorptive capacity of employees, knowledge sharing has direct positive relationship with firm innovation capability. Jantunen (2005) concluded that better knowledge sharing leads to superior firm innovation capability. His result follows the conclusion of several previous works, both in theoretical and empirical studies. For example, Yesil et al. (2013) extended study scope to analyze effect of knowledge sharing on innovation capability and innovation performance for the firm operating in Kahramanmaras. The study showed that only knowledge donating in knowledge sharing has significant impact on innovation capability. Recent research on innovation capability in Croatian ICT companies of Podrug et al. (2017) provides implication that knowledge sharing influences strongly to firm innovation capability. They argued that knowledge sharing is important for knowledge creation, which contributes substantially to innovation capability, and then firm performance can be improved. Therefore, it can be hypothesized that:

H2: Knowledge sharing practices including knowledge collecting and knowledge donating have positive impact on firm innovation capability.

There is strong linkage between individual innovation and company's innovation capability. According to Burton (2001), firm's innovation activities depend significantly on CEO's knowledge and ability to innovate. Andries \& Czarnitzki (2011) concluded that apart from CEO and managers, non-manager employees also have strong impact on firm innovation. Additionally, Liao et al. (2007) concluded that knowledge sharing among employees has to be transformed into employees' relevant capabilities to benefit the firm and affect firm's innovation capability. According to Ologbo et al. (2015), firms 
cannot achieve overall firm innovation capabilities without attaining innovation capabilities of employees working in the organization because overall firm innovation capabilities is the sum of all individual capabilities. Thus, they suggested that organizations should build platform for employees to exchange knowledge, increase employee innovation capabilities which in turn boost the overall organizational innovation capabilities. Therefore, we can hypothesize that: capability.

H3a: Individual innovation capability has positive effect on firm innovation

H3b: Individual innovation capability acts as mediator in the relationship between knowledge sharing and firm innovation capability.

\section{Methodology}

\section{Analytical framework}

Based on literature review and hypotheses development, an analytical framework is proposed to test impact of knowledge sharing on innovation capabilities. The framework is illustrated in Figure 1.

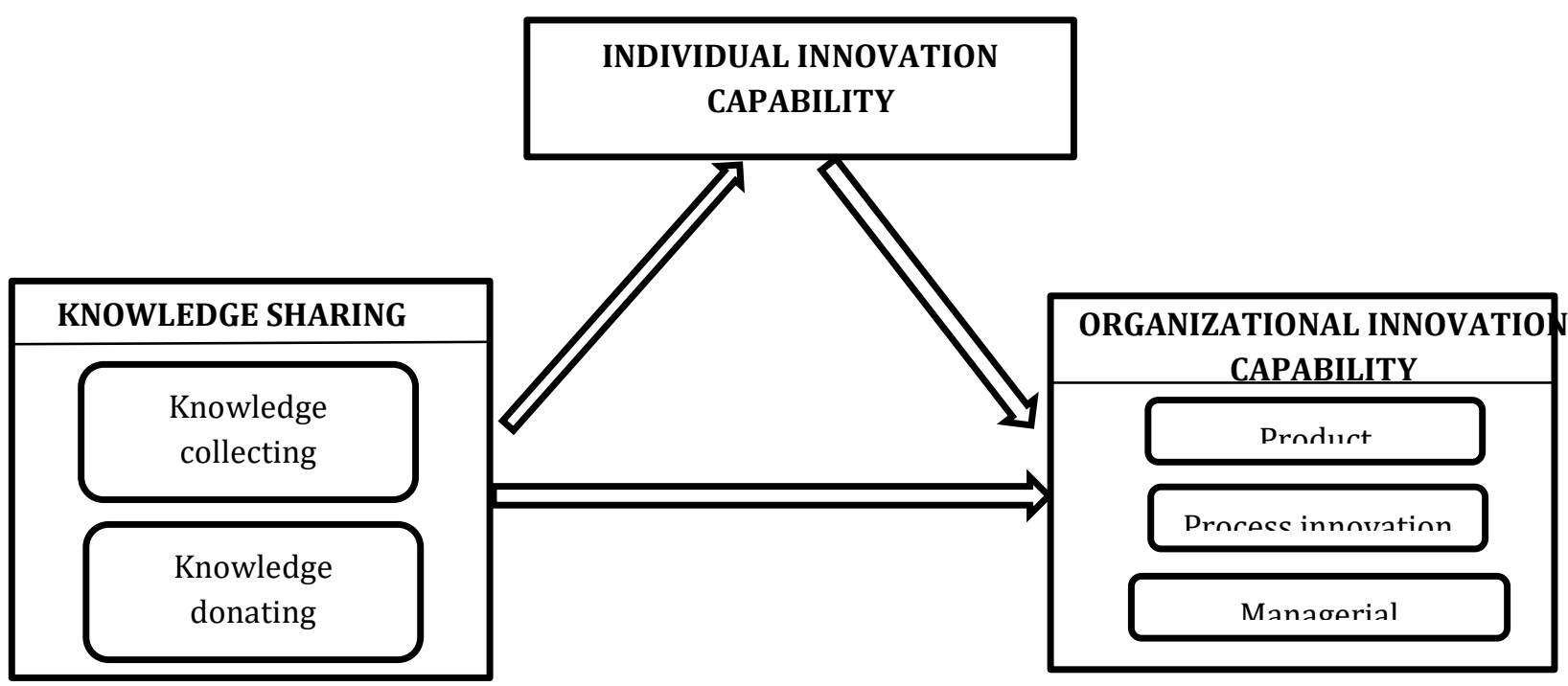

Figure 1. Analytical framework (compiled by authors)

In Figure 1, the meaning of each scale can be explained as follow:

- Knowledge collecting: Willingness of employees to seek for knowledge from colleagues and learn from them.

- Knowledge donating: Willingness of employees actively communicate with colleagues and contribute ideas to solve others' problem.

- Individual innovation capability: Willingness of employees to adopt something new and ability to create new ideas to achieve personal as well as organizational objectives.

- $\quad$ Product innovation: Organization's ability to utilize knowledge and ideas in developing new product and improving current products.

- Process innovation: Organization's ability to utilize knowledge and ideas in developing new way of doing things technically. 
- Managerial innovation: Organization's ability to develop new managerial regulations, systems and methods, in order to achieve organizational performance.

\section{Measurement of constructs}

Knowledge sharing between employees in the firm is measured mainly by knowledge collecting and knowledge donating, based on many previous researches (Lin et al., 2007, Liao et al., 2007, Ologbo et al., 2015). Table 2 summarizes the items to measure knowledge sharing, including knowledge donating and knowledge collecting.

Table 2. Measured Items for Knowledge sharing

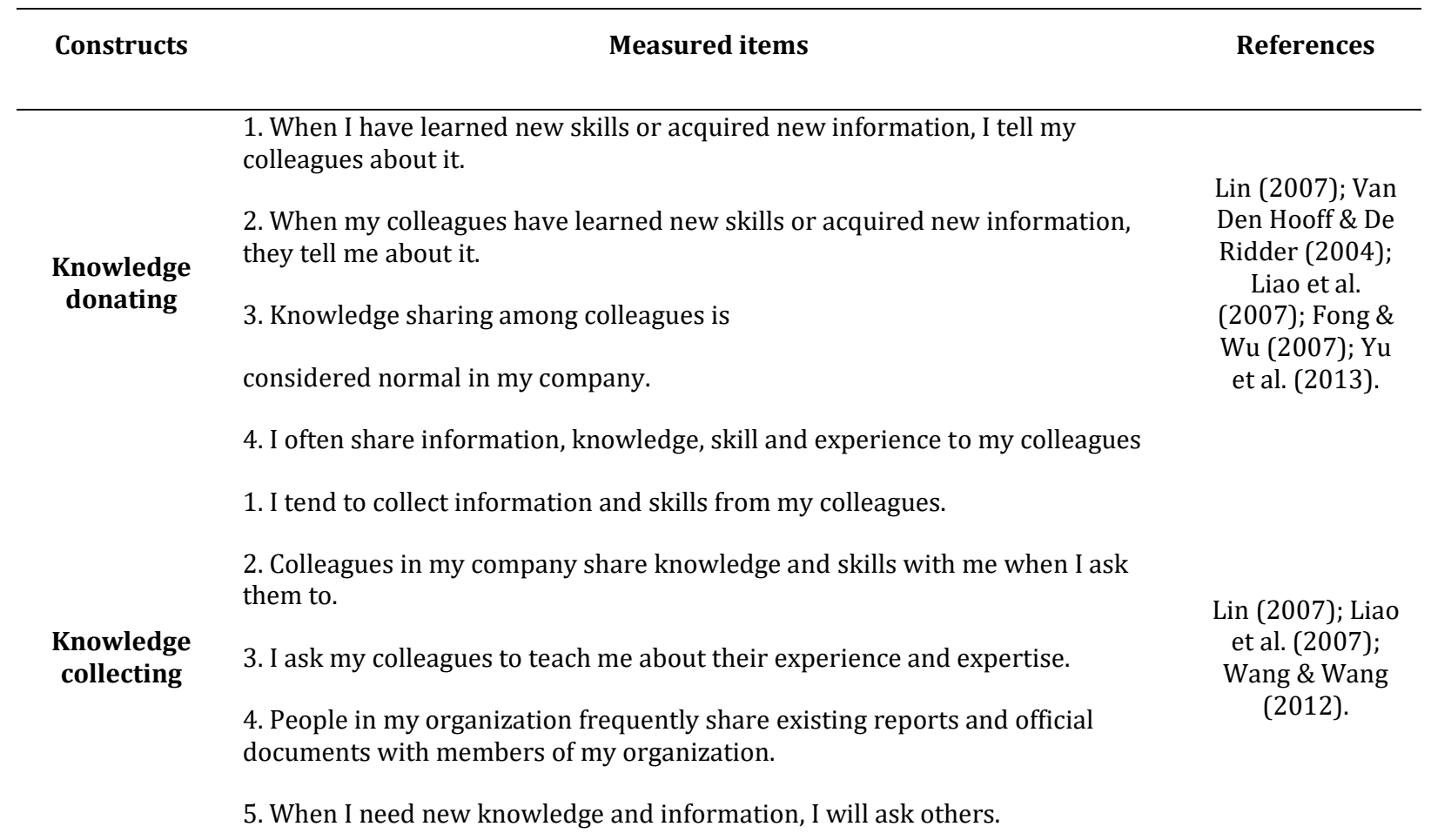

This study reviews previous studies (Liao et al., 2007; Lin, 2007; Calantone et al., 2002; Rahab et al., 2011; An et al., 2015) and select items to measure firm innovation capability. For individual innovation capability, the scale is developed early from Hurt et al. (1977), and Hollenstein (1996). Their measurements are well validated and adapted by subsequent studies (Calantone et al., 2002; An et al., 2015). Table 3 below describes in more detail how we can measure individual and firm innovation capability. 
Table 3. Measured items for individual and firm innovation capabilities

1. I enjoy trying out new ideas

2. I have strong eager of discovery leads to new ideas.

3. I seek out new ways to do things.

Individual innovation capability

4. I frequently improvise methods for solving a problem when an answer is not apparent.

5. I consider myself to be creative and original in my thinking and behavior.

6. I feel myself become more creative because of continuous learning in organization.

1. Our company often develops new products and services well accepted by the market.

2. Our company can often launch new products or services faster than our competitors.

Product innovation

3. Our company is frequently the first to market new products and services.

4. Our company has better capability in R\&D of new products or services than our competitors.

5. Our new product introduction has increased over the last 5 years.

1. Our company always acquires new skills or equipment to improve the manufacturing operation or service process.

\section{Firm innovation} capability
Process innovation

Managerial innovation
2. Our company can develop more efficient manufacturing process or operation procedure.

3. Our company is creative in its operating methods

4. Our company seeks new ways of doing things.

1. Our company's department heads will adopt new leadership approaches to lead all staff towards task completion.

2. Our company emphasizes innovative and creative capability when recruiting staff.

3. Staff are given incentives to generate new ideas as well as seek new ways of doing things.

4. Our company will change the division of work among different departments according to the needs of market management.
Hurt et al. (1977); Ganesan \& Weitz (1996); An et al. (2015).

Liao et al. (2007); Lin (2007); Calantone et al. (2002).

Liao et al. (2007); Lin (2007); Rahab et al. (2011).

Liao et al. (2007); An et al. (2015). 


\section{Data collection}

A questionnaire including multiple-item scales as mentioned above in Table 2 and Table 3. The questionnaire survey was designed to collect data from individuals working for Vietnam's telecommunication companies. Each item was evaluated on a seven-point scale ranging from (1) Strongly disagree to (7) Strongly agree. In order to reduce social desirability bias, the survey did not include any personal identification of the individuals, and the data analysis was restricted at an aggregated level. Prior to main survey, the questionnaire was pretested and revised to avoid interpretation errors and to increase the clarity of questions.

Regarding the main survey, we have contacted four largest domestic telecommunication companies in Vietnam including Viettel Telecom, Vinaphone, Mobifone, and FPT Telecom in Ha Noi (capital city in North of Vietnam), Da Nang (largest city in middle of Vietnam) and Ho Chi Minh (largest city in South of Vietnam). The place scope covers 3 big cities in Vietnam, which have dynamic working environment that facilitates communication as well as sharing behavior among employees. Those companies were selected because they are major players in the telecommunication industry in Vietnam; and practically, they are paying great attention in innovation as mentioned in the Introduction part. For example, FPT Telecom has been being famous for its innovative organizational culture, as the company respects everyone's strengths, weaknesses, and ideas of any employees are valued in company's meetings. Since the paper does not target at specific working positions, convenient sampling method was used to collect the data from various perspectives of employees from diverse positions and functions. Electronic link of questionnaire was sent to the person responsible for knowledge management in each organization. Those employees agreed to distribute the survey among their colleagues; thus, we cannot report about the response rate. The answer for questionnaire survey therefore is at individual level, measuring the variables by gathering employees' perception about individual and organizational innovation capability. Several previous studies have conducted similar sampling procedure (Akram et al, 2018; Podrug et al., 2017; Lin, 2007). Time to collect data is from December 2017 to February 2018. The survey collected 1,025 responses. Six hundred thirty three out of 1,025 responses were invalid and incomplete due to missing major values. Thus, the remaining 392 questionnaires were used for the analysis. Detail of the sample is provided in Table 4. 
Table 4. Sample description

\begin{tabular}{|c|c|c|c|}
\hline Category & Characteristic & Frequency & Percentage \\
\hline \multirow{4}{*}{ Company name } & FPT Telecom & 73 & 18.6 \\
\hline & Mobifone & 165 & 42.1 \\
\hline & Viettel Telecom & 96 & 24.9 \\
\hline & VNPT & 56 & 14.3 \\
\hline Industry & Telecommunication & 392 & 100 \\
\hline \multirow{2}{*}{ Company type } & State-owned & 292 & 74.5 \\
\hline & Private & 100 & 25.5 \\
\hline \multirow{5}{*}{ Size } & Below 100 & 21 & 5.4 \\
\hline & $101-200$ & 36 & 9.2 \\
\hline & $201-300$ & 151 & 38.5 \\
\hline & $301-500$ & 40 & 10.2 \\
\hline & Over 500 & 144 & 36.7 \\
\hline \multirow{3}{*}{ Workplace } & Hanoi & 283 & 72.2 \\
\hline & Da Nang & 61 & 15.6 \\
\hline & Ho Chi Minh & 48 & 12.2 \\
\hline \multirow{2}{*}{ Gender } & Male & 217 & 55.4 \\
\hline & Female & 175 & 44.6 \\
\hline \multirow{5}{*}{ Education level } & High school & 1 & 0.3 \\
\hline & Vocational & 18 & 4.6 \\
\hline & College & 38 & 9.7 \\
\hline & Bachelor & 276 & 70.4 \\
\hline & Master or Doctor & 59 & 15.1 \\
\hline
\end{tabular}


In particular, data sample has a balance regarding gender $(55.4 \%$ are male, $44.6 \%$ are female). Most of respondents have finished bachelor study or upper (85.5\%). Thus, we assume that respondents are more oriented to knowledge sharing practices because they are well-educated. Lastly, it can be seen that employees including in the sample are diverse in terms of age, working experience and position. Therefore, the sample in this study can be generalized for the pull sample in some extent.

\section{Data analysis}

\section{Descriptive analysis}

The first step in analytical process is descriptive analysis, which is performed to provide minimum value, maximum value, mean value, standard deviation of the scales. The result is summarized in Table 5.

Table 5. Descriptive analysis

\begin{tabular}{ccccc}
\hline Scale & Min & Max & Mean & $\begin{array}{c}\text { Standard } \\
\text { deviation }\end{array}$ \\
\hline $\begin{array}{c}\text { Knowledge } \\
\text { collecting }\end{array}$ & 1.00 & 7.00 & 5.02 & 1.20 \\
$\begin{array}{c}\text { Knowledge } \\
\text { donating }\end{array}$ & 1.00 & 7.00 & 5.03 & 1.23 \\
$\begin{array}{c}\text { Individual } \\
\text { innovation } \\
\text { capability }\end{array}$ & 1.00 & 7.00 & 5.02 & 1.16 \\
$\begin{array}{c}\text { Product } \\
\text { innovation } \\
\text { capability }\end{array}$ & 1.00 & & & \\
$\begin{array}{c}\text { Process innovation } \\
\text { capability }\end{array}$ & 1.00 & 7.00 & 4.98 & 1.23 \\
$\begin{array}{c}\text { Managerial } \\
\text { innovation } \\
\text { capability }\end{array}$ & 1.00 & 7.00 & 5.14 & 1.28 \\
\hline
\end{tabular}

Regarding mean value, it can be observed that there is an equality between knowledge collecting and knowledge donating, based on employees' perspectives. When it comes to organizational innovation capability, managerial innovation capability exhibits the highest mean value (5.17), followed by process innovation capability (5.14) and product innovation capability (4.98). It implies that managerial innovation capability is viewed by employees as most contribution for organizational innovation capability in Vietnamese telecommunication companies, while product innovation capability shows lowest contribution. 


\section{Reliability and validity test}

Reliability and factor analysis

Reliability test is implemented to ensure the internal consistency between items measuring same construct. The indicator mostly used to analyze reliability is Cronbach's Alpha, with acceptable value is greater than 0.6 for each scale (Nunnally, 1978; Peterson, 1994; Slater, 1995). Exploratory factor analysis (EFA) is a statistical method that is commonly used by researchers to uncover the underlying structure of a relatively large set of variables (Norris \& Lecavalier, 2009). EFA is recommended to be performed when there was no prior hypothesis about factors or patterns of measured variables. Mayers et al. (2012) indicated that the most popular way to fulfill EFA is using SPSS along with the use of "Dimension reduction" technique with "Principle component analysis" extraction method and "Varimax with Kaiser Normalization" rotation method. Since questionnaire items in this paper were adapted from various researches, we want to convergent validity of the underlying factors by EFA.

The result confirms satisfactory reliability of all scales as well as all questionnaire items. It can be seen that all Cronbach's Alpha are larger than 0.6, and values of Item total correlation are in excess of 0.4 . Therefore, within a construct, all questionnaire items are linked strongly together, and they are reliable for further analysis.

EFA results show that all KMO value are inside the range from 0.5 to $1(0.86,0.90$ and 0.94). Besides, Eigenvalues of all extracted components are greater than 1, all percentage of variance values exceed $50 \%$, implying that measuring questionnaire items can explain over $50 \%$ the variability of underlying construct. Additionally, since all factor loadings are in excess of 0.6, all scales as well as items are kept for the next step.

To summarize, EFA result indicates that:

- $\quad$ Knowledge sharing practices are shortened into two separated variables, called "Knowledge collecting" and "Knowledge donating".

- Individual innovation capability items are linked and there is only one component is extracted. Hence, individual innovation capability is a single construct.

- Organizational innovation capability is extracted into three independent components namely "Product innovation", "Process innovation" and "Managerial innovation". These are 3 types of innovation capability to measure organizational innovation performance. 
Table 6. Reliability and factor analysis

\begin{tabular}{|c|c|c|c|c|c|c|c|}
\hline Construct & $\begin{array}{l}\text { Measurement } \\
\text { items }\end{array}$ & $\begin{array}{c}\text { Item total } \\
\text { correlation }\end{array}$ & $\begin{array}{c}\text { Cronbach's } \\
\text { Alpha }\end{array}$ & Eigenvalues & KMO & $\begin{array}{l}\text { Percentage } \\
\text { of variance }\end{array}$ & $\begin{array}{r}\text { Factor } \\
\text { loading }\end{array}$ \\
\hline \multirow{5}{*}{$\begin{array}{l}\text { Knowledge } \\
\text { collecting }\end{array}$} & KC1 & 0.74 & \multirow{5}{*}{0.90} & \multirow{5}{*}{4.50} & & & 0.81 \\
\hline & KC2 & 0.76 & & & & & 0.85 \\
\hline & KC3 & 0.80 & & & & & 0.88 \\
\hline & KC4 & 0.75 & & & & & 0.84 \\
\hline & KC5 & 0.72 & & & 0.86 & 75.33 & 0.78 \\
\hline \multirow{4}{*}{$\begin{array}{l}\text { Knowledge } \\
\text { donating }\end{array}$} & KD1 & 0.83 & \multirow{4}{*}{0.91} & \multirow{4}{*}{2.29} & & & 0.91 \\
\hline & KD2 & 0.85 & & & & & 0.92 \\
\hline & KD3 & 0.72 & & & & & 0.80 \\
\hline & KD4 & 0.80 & & & & & 0.89 \\
\hline \multirow{7}{*}{$\begin{array}{l}\text { Individual } \\
\text { innovation } \\
\text { capability }\end{array}$} & IIC1 & 0.85 & \multirow{7}{*}{0.94} & \multirow{7}{*}{4.62} & \multirow{7}{*}{0.90} & \multirow{7}{*}{76.93} & 0.91 \\
\hline & IIC2 & 0.85 & & & & & 0.91 \\
\hline & IIC3 & 0.85 & & & & & 0.91 \\
\hline & & & & & & & \\
\hline & IIC4 & 0.85 & & & & & 0.90 \\
\hline & IIC5 & 0.63 & & & & & 0.72 \\
\hline & IIC6 & 0.85 & & & & & 0.90 \\
\hline \multirow{5}{*}{$\begin{array}{l}\text { Product } \\
\text { innovation } \\
\text { capability }\end{array}$} & Product_IC1 & 0.85 & \multirow{6}{*}{0.95} & \multirow{6}{*}{8.84} & & & 0.76 \\
\hline & Product_IC2 & 0.91 & & & & & 0.87 \\
\hline & Product_IC3 & 0.92 & & & & & 0.86 \\
\hline & Product_IC4 & 0.91 & & & & & 0.85 \\
\hline & Product_IC5 & 0.88 & & & & & 0.83 \\
\hline \multirow{5}{*}{$\begin{array}{l}\text { Process } \\
\text { innovation } \\
\text { capability }\end{array}$} & Process_IC1 & 0.91 & & & & & 0.87 \\
\hline & Process_IC2 & 0.91 & \multirow{4}{*}{0.95} & \multirow{4}{*}{1.58} & 0.94 & 88.24 & 0.88 \\
\hline & & & & & & & \\
\hline & Process_IC3 & 0.92 & & & & & 0.85 \\
\hline & Process_IC4 & 0.90 & & & & & 0.89 \\
\hline \multirow{5}{*}{$\begin{array}{l}\text { Managerial } \\
\text { innovation } \\
\text { capability }\end{array}$} & Manage_IC1 & 0.88 & \multirow{5}{*}{0.95} & \multirow{5}{*}{1.05} & & & 0.82 \\
\hline & Manage_IC2 & 0.90 & & & & & 0.82 \\
\hline & & & & & & & \\
\hline & Manage_IC3 & 0.89 & & & & & 0.83 \\
\hline & Manage_IC4 & 0.85 & & & & & 0.79 \\
\hline
\end{tabular}




\section{Discriminant validity}

Discriminant validity is performed to ensure all latent variables are unrelated, based on the rule of Fornell \& Larcker (1981). Discriminant validity is acceptable when average variance extracted (AVE) of a factor is larger than any bivariate correlation between that factor and others. The result of discriminant validity is shown in Table 7, indicating that all variables demonstrate good discriminant validity.

Table 7. Discriminant validity testing

\begin{tabular}{ccccccc}
\hline & $\begin{array}{c}\text { Knowledge } \\
\text { collecting }\end{array}$ & $\begin{array}{c}\text { Knowledge } \\
\text { donating }\end{array}$ & $\begin{array}{c}\text { Individual } \\
\text { innovation } \\
\text { capability }\end{array}$ & $\begin{array}{c}\text { Product } \\
\text { innovation } \\
\text { capability }\end{array}$ & $\begin{array}{c}\text { Process } \\
\text { innovation } \\
\text { capability }\end{array}$ & $\begin{array}{c}\text { Managerial } \\
\text { innovation } \\
\text { capability }\end{array}$ \\
\hline $\begin{array}{c}\text { Knowledge } \\
\text { collecting }\end{array}$ & $\mathbf{0 . 4 5}$ & & & & & \\
$\begin{array}{c}\text { Knowledge } \\
\text { donating }\end{array}$ & 0.19 & $\mathbf{0 . 7 3}$ & & & & \\
$\begin{array}{c}\text { Individual } \\
\text { innovation } \\
\text { capability }\end{array}$ & 0.18 & 0.60 & $\mathbf{0 . 7 1}$ & & & \\
$\begin{array}{c}\text { Product } \\
\text { innovation } \\
\text { capability }\end{array}$ & 0.16 & 0.48 & 0.50 & $\mathbf{0 . 8 4}$ & & \\
$\begin{array}{c}\text { Process } \\
\text { innovation } \\
\text { capability }\end{array}$ & 0.07 & 0.23 & 0.29 & 0.40 & $\mathbf{0 . 8 7}$ & \\
$\begin{array}{c}\text { Managerial } \\
\text { innovation } \\
\text { capability }\end{array}$ & 0.12 & 0.48 & 0.58 & 0.55 & 0.44 & $\mathbf{0 . 8 3}$ \\
\hline
\end{tabular}

Bold numbers show average variance extracted values; others show square correlations between constructs.

\section{Structural model}

\section{Model fit evaluation}

Before doing path analysis to test hypotheses, it is necessary to assess the fit of structural model. There are several indices to evaluate the goodness of fit. Comparative fit index (CFI) exceeding 0.9 indicates a goodness of fit (Baumgartner \& Hombur, 1996). Adjusted goodness-of-fit index (AGFI) is suggested to exceed 0.8 for an acceptable fit (Chau \& Hu, 2001). Discrepancy function divided by degree of freedom (CMIN/DF) suggested by Bagozzi \& Yi (1988) should has a value smaller than 3. Bollen (1989) developed some indices to measure the model fit, including normal fit index (NFI), incremental fit index (IFI) and relative fit index (RFI). It indicates more fit if NFI, IFI and RFI are closer to 1 , normally greater than 0.9 is acceptable. In addition, based on $\mathrm{Hu} \&$ Bentler (1999), Tucker Lewis index (TLI) is bigger than 0.9, root mean square error of approximation (RMSEA) is smaller than 0.08 would be acceptable for model fit. Table 8 presents the results for those indices above, showing good model fit for further analysis. 
Table 8. Model fit evaluation

\begin{tabular}{cccc}
\hline Index & Observed value & Optimal value & Evaluation \\
\hline CFI & 0.95 & $>0.9$ & Satisfied \\
AGFI & 0.82 & $>0.8$ & Satisfied \\
CMIN/DF & 2.89 & $<3$ & Satisfied \\
NFI & 0.92 & $>0.9$ & Satisfied \\
IFI & 0.95 & $>0.9$ & Satisfied \\
RFI & 0.91 & $>0.9$ & Satisfied \\
TLI & 0.94 & $>0.9$ & Satisfied \\
RMSEA & 0.07 & $<0.08$ & Satisfied \\
\hline
\end{tabular}

\section{Hypothesis testing}

Afer confirming the validity of the structural model, next step is to estimate the coefficients of relationships to validate hypotheses. For H1, H2 and H3a, the authors want to investigate relationships between knowledge sharing, individual innovation capability and organizational innovation capability. Results showing in Figure 2 and Table 9 found that $\mathrm{H} 1, \mathrm{H} 3 \mathrm{a}$ are supported, and $\mathrm{H} 2$ is partially supported.

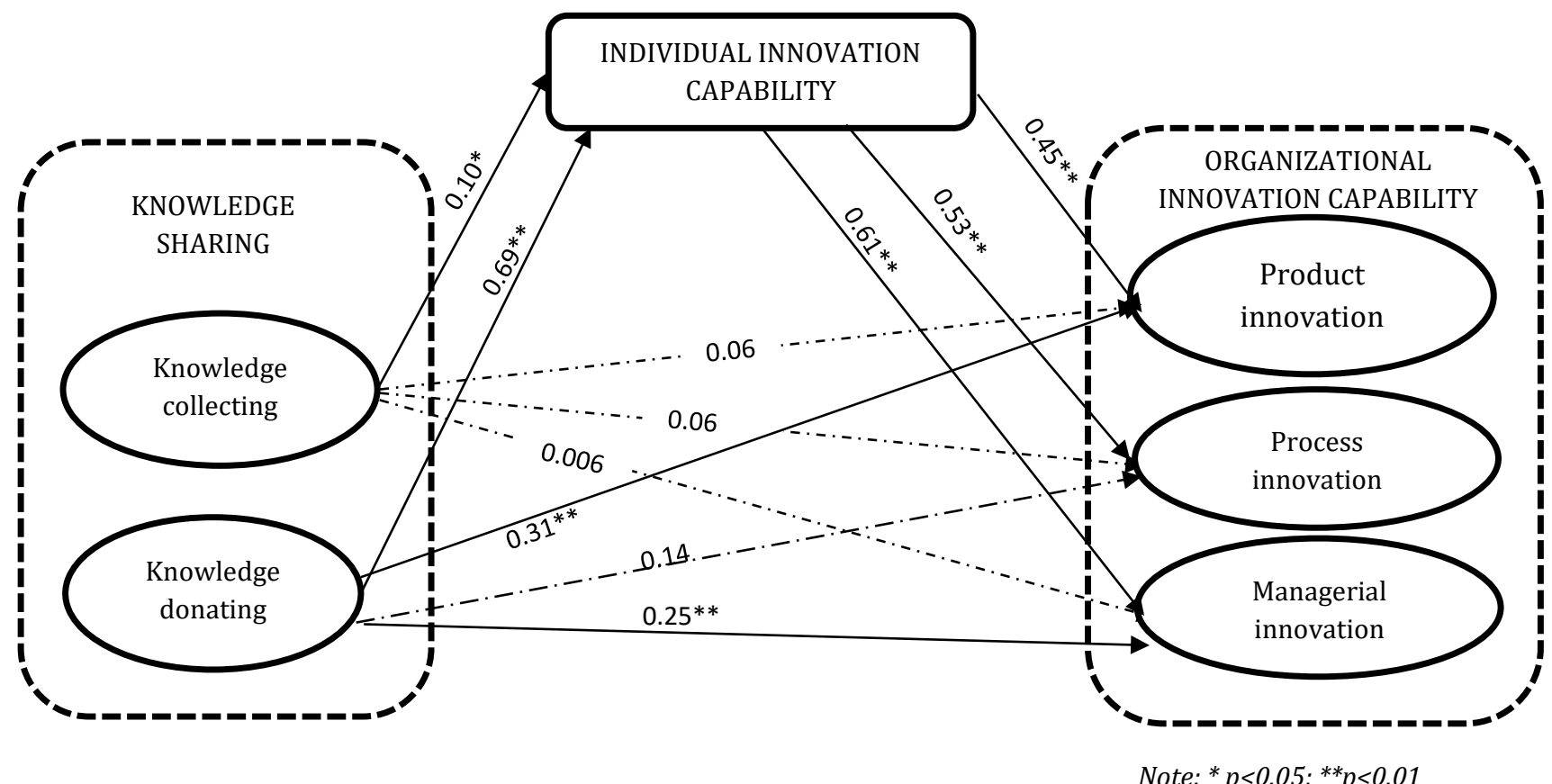

Figure 2. Coefficients estimation 
Table 9. Hypothesis testing (H1, H2, H3a)

\begin{tabular}{|c|c|c|c|c|}
\hline Hypothesis & Relationship & Coefficient & Critical ratio & Result \\
\hline \multirow[b]{2}{*}{$\mathrm{H} 1$} & $\begin{array}{c}\text { Knowledge collecting } \rightarrow \\
\text { Individual innovation capability }\end{array}$ & $0.10^{*}$ & 2.50 & Supported \\
\hline & $\begin{array}{c}\text { Knowledge donating } \rightarrow \\
\text { Individual innovation capability }\end{array}$ & $0.69^{* *}$ & 15.10 & Supported \\
\hline \multirow{6}{*}{$\mathrm{H} 2$} & $\begin{array}{c}\text { Knowledge collecting } \rightarrow \text { Product } \\
\text { innovation capability }\end{array}$ & 0.06 & 1.48 & $\begin{array}{c}\text { Not } \\
\text { supported }\end{array}$ \\
\hline & $\begin{array}{c}\text { Knowledge collecting } \rightarrow \text { Process } \\
\text { innovation capability }\end{array}$ & 0.06 & 1.12 & $\begin{array}{c}\text { Not } \\
\text { supported }\end{array}$ \\
\hline & $\begin{array}{c}\text { Knowledge collecting } \rightarrow \\
\text { Managerial innovation capability }\end{array}$ & 0.006 & 0.14 & $\begin{array}{c}\text { Not } \\
\text { supported }\end{array}$ \\
\hline & $\begin{array}{c}\text { Knowledge donating } \rightarrow \text { Product } \\
\text { innovation capability }\end{array}$ & $0.31^{* *}$ & 5.30 & Supported \\
\hline & $\begin{array}{c}\text { Knowledge donating } \rightarrow \text { Process } \\
\text { innovation capability }\end{array}$ & 0.14 & 1.73 & $\begin{array}{c}\text { Not } \\
\text { supported }\end{array}$ \\
\hline & $\begin{array}{c}\text { Knowledge donating } \rightarrow \\
\text { Managerial innovation capability }\end{array}$ & $0.25^{* *}$ & 4.20 & Supported \\
\hline \multirow{3}{*}{ H3a } & $\begin{array}{l}\text { Individual innovation capability } \\
\rightarrow \text { Product innovation capability }\end{array}$ & $0.45^{* *}$ & 6.94 & Supported \\
\hline & $\begin{array}{l}\text { Individual innovation capability } \\
\rightarrow \text { Process innovation capability }\end{array}$ & $0.53^{* *}$ & 5.80 & Supported \\
\hline & $\begin{array}{l}\text { Individual innovation capability } \\
\rightarrow \text { Managerial innovation } \\
\text { capability }\end{array}$ & $0.61^{* *}$ & 9.09 & Supported \\
\hline
\end{tabular}

Hypothesis $\mathrm{H} 3 \mathrm{~b}$ argues the mediating effect of individual innovation capability on relationship between knowledge sharing and organizational innovation capability. To test this hypothesis, indirect effects of knowledge sharing on organizational innovation capability through individual innovation capability are tested by using bootstrapping technique (Cheung \& Lau, 2008). The two-tailed significance shows the significance of indirect (mediated) effects of independent variable on dependent variable, via a mediator. Table 10 shows that all two-tailed significance are smaller than 0.05 , so we can conclude that individual innovation capability has mediating impact on relationship between knowledge sharing and organizational innovation capability, at 5\% of significant level. Therefore, hypothesis H3b is supported. 
Table 10. Testing indirect effects - two tailed significance (Bootstrap Confidence)

Mediator: Individual innovation capability

\begin{tabular}{ccc}
\hline Indirect relationship & $\begin{array}{c}\text { Two tailed significance (p- } \\
\text { value) }\end{array}$ & Evaluation \\
\hline $\begin{array}{c}\text { Knowledge collecting } \rightarrow \text { Product } \\
\text { innovation capability }\end{array}$ & 0.029 & Significant \\
$\begin{array}{c}\text { Knowledge collecting } \rightarrow \text { Process } \\
\text { innovation capability }\end{array}$ & 0.030 & Significant \\
$\begin{array}{c}\text { Knowledge collecting } \rightarrow \text { Managerial } \\
\text { innovation capability } \\
\text { Knowledge donating } \rightarrow \text { Product } \\
\quad \text { innovation capability } \\
\begin{array}{c}\text { Knowledge donating } \rightarrow \text { Process } \\
\text { innovation capability }\end{array}\end{array}$ & 0.034 & Significant \\
$\begin{array}{c}\text { Knowledge donating } \rightarrow \text { Managerial } \\
\text { innovation capability }\end{array}$ & 0.005 & Significant \\
\hline
\end{tabular}

\section{Robustness assessment - Nonlinear effects}

Literature has shown high adoption rate of Partial Least Square - Structural Equation Modeling (PLS-SEM) technique in data analysis because of many conveniences it brings. However, the robustness of the result can be improved by several tests, which can be named as nonlinear effects, endogeneity and unobserved heterogeneity (Sarstedt, et al., 2019). We understand that there should be many other factors that can influence innovation, and the effect might be different among various sub-groups of data. However, since this paper only focus on effect of knowledge sharing on innovation without considering any control variables, we do not assess the endogeneity and unobserved heterogeneity, only non-linear effect particularly quadratic effect is tested. We assume that knowledge sharing initially can improve individual creativity, but too much knowledge sharing behavior can make employees overwhelm with a lot of redundant knowledge, therefore hinder their innovative capability. In short, whether knowledge sharing has quadratic impact on individual innovation capability is tested to assess the robustness of our results.

Following Svensson et al. (2018), non-linear effect assessment consists of 2 steps: First, we perform Ramsey RESET test to see wheter quadratic impact exists in the relationship between knowledge collecting, knowledge donating and individual innovation capability. Second, the significance of quadratic variables is checked. This process was done by using SmartPLS 3.0 software. The result is summarized in Table 11.

Table 11. Robustness assessment - Nonlinear effect

\begin{tabular}{|c|c|c|c|c|}
\hline $\begin{array}{c}\text { Nonlinear } \\
\text { relationship }\end{array}$ & Coefficient & t-statistic & p-value & Ramsey RESET \\
\cline { 1 - 3 } KC*KC $\rightarrow$ IIC & -0.048 & 1.172 & 0.238 & \multirow{F}{*}{$\begin{array}{c}\text { IC }(3,388)=0.000027 \\
\text { p-value = close to 1 }\end{array}$} \\
\cline { 1 - 3 } KD*KD $\rightarrow$ IIC & -0.037 & 1.127 & 0.260 & Note: KC: knowledge collecting, KD: knowledge donating, IIC: Individual innovation capability
\end{tabular}


The Ramsey RESET indicators suggest that the hypothesis "H0: There is no nonlinear effect" should not be rejected because the F statistic is too small. We further calculate the coefficients of quadratic variables by including them in the regression model together with ordinary variables that are knowledge collecting and knowledge donating. The result indicates two estimates of $\mathrm{p}$-value that are greater than 0.05 , therefore neither of the nonlinear effects is significant. Consequently, we conclude that there is no hindering nonlinear effect, and robustness of the linear effects model is confirmed.

\section{Discussions and implications}

\section{Main findings}

Main purpose of this paper is to evaluate the relationship among knowledge sharing practices, individual innovation capability and organizational capability in Vietnamese telecommunication companies. Through extensive literature review, an analytical framework is proposed, aiming at breaking down innovation capability into 2 levels (individual and organizational) especially categorizing 3 types of organizational innovation capability (product, process and managerial innovation). The main findings of this paper are discussed as below.

The first finding is described through descriptive analysis. Result shows that product innovation exhibits lowest mean value among 3 types of organizational innovation, while managerial innovation represents highest value. It reflects current situation of telecommunication industry in Vietnam that there is limited innovative products and services, innovation mostly comes from management such as changing in leadership style, the way of human resource management. Although there are more and more private investors in telecommunication industry in Vietnam, state-owned enterprises still have dominant market share and play key roles in the industry. As a result, competitive pressure is relatively low compared to other industries, leading to lessen innovation that derived from telecommunication companies. Furthermore, it is difficult to introduce radical product innovation in telecommunication industry, unless there is a huge change in technology development.

Second finding in this paper indicates positive impact of knowledge sharing on individual innovation capability and firm innovation capability. Relationship between knowledge sharing and firm innovation capability is confirmed in many extant literature (Jantunen, 2005; Lin, 2007; Song et al., 2008). However, there are limited studies that break down firm innovation capability into 3 independent types of innovation. This study found that employee's willingness to collect knowledge has no direct impact on product, process, managerial innovation. Besides, willingness of donating knowledge can improve product and managerial innovation significantly. The finding suggests that to implement new ideas or process, it requires knowledge sharing culture to disseminate knowledge throughout organization, thus linking all staff and creating synergistic effect to improve organizational innovation (Lin, 2007). When it comes to product and managerial innovation, companies are recommended to encourage collaboration among employees in different function, also raise as many employees' opinion as possible to 
find out new and effective way of management. In addition, association of knowledge sharing and individual innovation capability can be found in several previous works such as Lee (2018); Hu \& Zhao (2016); Jaberi (2016). Yuan \& Woodman (2010) indicated that knowledge exchange is profound to solve problems creatively in the workplace, because it helps to improve employees' mindset or cognitive capacity. Therefore, it is implied for managers to create supportive environment for knowledge exchange between employees, or provide training program, open discussion. It would help to better employee socialization, as well as enrich individual knowledge, leading to higher firm performance (Cummings \& Oldham, 1997).

Subsequently, this paper found that individual innovation capability should be premise before achieving firm innovation capability, and higher individual innovation will result in higher organizational innovation. This result is similar in the study of An et al. (2015). It was argued in previous research that innovative ideas are first derived from individuals, those ideas are shared between group later and finally, they are implemented by employees in different function within company (Ologbo, 2015). Thus, when it is limited in product and process innovation in Vietnam's telecommunication industry, knowledge sharing practices are recommended to contribute to competitive advantage especially innovation (Wang \& Wang, 2012). Equally important, it is noticeable that quality of knowledge sharing should be focused rather than intensity or volume of knowledge sharing (Lee, 2018). In case that knowledge is intensively shared, employees may feel overwhelmed and confused to apply the knowledge in practice. So, it requires company to have good management of social networks or other information communication technology (ICT) supports, which help to sustain sharing culture and build trust among employees.

The last finding in this paper shows that individual innovation capability acts as a mediating variable between knowledge sharing practices and firm innovation capability. This study indicates that if individual innovation is inadequate, knowledge sharing practices will have less direct impact on firm innovation capability, and vice versa. When knowledge sharing activities within firms can be implemented by people who have high competencies, knowledge learning among employees will be more effective, then the organization will be able to manage knowledge efficiently. This finding contributes to the work of Liao et al. (2007), showing that knowledge sharing can enhance employee's skills and motivation, then strengthen firm innovation capability. Once again, importance of individual innovation capability is confirmed as a key to enhance firm innovation strategy. Companies are suggested to empower, encourage employees to raise their enthusiasm of innovation, then creating creative workplace.

\section{Implications}

In general, this paper contributes to the literature and practice by: (1) verifying the effects of knowledge sharing behaviors including knowledge collecting \& knowledge donating on organizational innovation capability via individual innovation capability as a mediator; (2) providing empirical evidence of how knowledge sharing drives innovation in the context of Vietnamese telecommunication industry. Namely, under 
theoretical perspective, this study highlights the crucial role of individual innovation capability, which not only has direct effect on firm innovation capability, but it also plays as mediator fostering impact of knowledge sharing on product, process, and managerial innovation capability. This study contributes to the field of knowledge management and how to manage innovation effectively. Many researches have been focused on investigating the direct effect of knowledge sharing including knowledge collecting, knowledge donating on firm innovation capability. However, the findings are somewhat different. For example, Chan et al. (2017) and Podrug et al. (2017) found that knowledge donating and collecting have positive impact on firm innovation. Studies of Tassabehji (2019) and Yesil et al. (2013) point out the importance of knowledge donating only, while knowledge collecting has no significant impact on innovation. Besides, Kamasak and Bulutlar (2010) indicated that knowledge collecting has effect on all types of innovation, and knowledge donating has no influence on exploratory innovation. Inconsistency in existing literature motivates this study to develop more completed model illustrating relationship between knowledge sharing and innovation. Managers can utilize the findings in this study to implement knowledge sharing practices to drive specific type of innovation. We can remark that knowledge sharing practices should be implemented to boost up firm innovation, especially in the context with relatively low competitiveness such as telecommunication industry in developing country like Vietnam. Importantly, company should put the employees at the center of innovation because increasing employee's innovation capability through knowledge sharing would help to build up organizational knowledge as a whole and enhance firm innovation capability.

\section{Conclusions}

This study provides empirical evidence by testing research framework related to knowledge sharing practices (knowledge collecting, knowledge donating), individual innovation capability and firm innovation capability (product innovation, process innovation, managerial innovation) in the context of Vietnam's telecommunication industry. Data sample were collected from 392 respondents in Vietnamese telecommunication companies, which are diverse in workplace and working experience.

Most of the findings are satisfied with authors' initial arguments, except the direct link between knowledge sharing and organizational innovation capability. Knowledge collecting has no direct impact on organizational innovation capability, and knowledge donating is found to have direct positive impact on product and managerial innovation capability but not process innovation capability. Results of this paper confirm significant effect of knowledge sharing on individual innovation capability, and individual innovation capability was found as a determinant of product, process and managerial innovation capability. More importantly, it confirms the hypothesis that there is significant mediating role of individual innovation capability on the relationship between knowledge sharing and firm innovation capability. Theoretically, current study proposes a conceptual framework that considers innovation capability in two levels: individual and organizational, as well as divide organizational innovation into three 
types: product innovation, process innovation and managerial innovation. Practically, knowledge sharing practices are emphasized within companies to facilitate employee socialization, enlarge employee's cognitive capacity as well as improve firm's competitive advantage regarding innovation. Specially, effect of each knowledge sharing practice on each type of innovation capability is provided. Managers can utilize analysis result in this work, depend on their objective of improving a specific kind of innovation capability.

It is important to view this study under its limitations. Firstly, data sample were collected during short period of time, so it leads to unexpected sample size with low response rate. Future researches can collect more data to re-examine the framework in wider context, so that providing results that are more generalizable. Moreover, another statistical technique could be used to provide more interesting results, such as implementing path analysis, adding control variables, etc. Second limitation in this paper is that questionnaire survey is based on perceptual data. It may create bias because there is involvement of personal opinion. This limitation can be handled by future works by measuring innovation capability by both subjective and objective way. Another method is undertaking longitudinal studies, consider impact of knowledge sharing on innovation in a long period of time. Lastly, more variables can be added into the model to fully understand determinants of knowledge sharing as well as innovation capability.

\section{References}

Akram, T., Lei, S., Haider, M., \& Hussain, S. (2018) 'Exploring the Impact of Knowledge Sharing on the Innovative Work Behavior of Employees: A Study in China', International Business Research, Vol. 11 No. 3, pp. 186-194.

Alavi, M., Kayworth, T., \& Leidner, D. (2005) 'An Empirical Examination of the Influence of Organizational Culture on Knowledge Management Practices', Journal of Management Information Systems, Vol. 22 No. 3, pp. 191-224.

An, N., Anh, N., Chinh, D., Hong, L., Son, L., \& Tuan, N. (2015) 'Factors affecting employee creativity \& its impact on organizational innovation capability in state owned banks in Hanoi, Vietnam'. Paper presented at the Proceedings of 47th The IIER International Conference, (pp. 23-30). Bangkok, Thailand.

Andrews, K., \& Delahaye, B. (2000) 'Influences On Knowledge processes In Organizational Learning: The Psychosocial Filter', Journal of Management Studies, Vol. 37 No. 6, pp. 2322-2380.

Andries, P., \& Czarnitzki, D. (2014) 'Small firm innovation performance and employee involvement', Small Business Economics, Vol. 43 No. 1, pp. 21-38.

Anwahi, F. (2012) The effect of knowledge sharing on employee innovation in media organization. Dissertation submitted in partial fulfilment of MSc in Project Management.

Aryanto, R., Fontana, A., \& Afiff, A. (2015) 'Strategic Human Resource Management, Innovation Capability and Performance: An Empirical Study in Indonesia Software Industry', Procedia - Social and Behavioral Sciences, Vol. 211, pp. 874-879.

Aulawi, H., Sudirman, I., Suryadi, K., \& Govindaraju, R. (2009) 'Knowledge Sharing Behavior, Antecedent and Their Impact on the Individual Innovation Capability', Journal of Applied Sciences Research, Vol. 5 No. 12, pp. 2238-2246.

Bagozzi , R., \& Yi, Y. (1988) 'On the evaluation of structural equation model', Journal of Academy of Marketing Science, Vol. 16 No. 1, pp. 74-94.

Baron, R., \& Kenny, D. (1986) 'The moderator-mediator variable distinction in social psychological research: Conceptual, strategic, and statistical considerations', Journal of Personality and Social Psychology, Vol. 51 No, 6, pp. 1173-1182. 
Bartol, K., \& Srivastava, A. (2002) 'Encouraging Knowledge Sharing: The Role of Organizational Reward Systems', Journal of Leadership and Organizational Studies, Vol. 9 No, 1, pp. 64-76.

Baumgartner, H., \& Hombur, C. (1996) 'Applications of structural equation modeling in marketing and consumer research: a review', International Journal of Research in Marketing, Vol. 13 No. 2, pp. 139-161.

Bollen, K. (1989) Structural Equations with Latent Variables, John Wiley \& Sons, New York.

Burgelman, R., Christensen, C., \& Wheelwright, S. (2004) Strategic Management of Technology and Innovation, 5th ed.,McGraw-Hill Education, New York.

Burton, D. (2001) The company they keep: Founders' models for organizing new firms. In C. Schoonhoven, \& E. Romanelli, The Entrepreneurship Dynamic: Origins of Entrepreneurship and the Evolution of Industries (pp. 13-39). CA: Stanford University Press.

Calantone, R., Cavusgil, S., \& Zhao, Y. (2002) 'Learning orientation, firm innovation capability, and firm performance, Industrial Marketing Management', Industrial Marketing Management, Vol. 31 No. 6, pp. 515-524.

Canh, N., Liem, N., Thu, P., \& Khuong, N. (2019) 'The Impact of Innovation on the Firm Performance and Corporate Social Responsibility of Vietnamese Manufacturing Firms', Sustainability, Vol. 11 No. 13, 3666.

Chang, W., Liao, S., \& Wu, T. (2017) 'Relationships among organizational culture, knowledge sharing, and innovation capability: a case of the automobile industry in Taiwan', Knowledge Management Research \& Practice, Vol. 15 No. 3, pp. 471-490.

Chau, P., \& Hu, P. (2001) 'Information technology acceptance by individual professionals: a model comparison approach', Decision Sciences, Vol. 34 No. 4, pp. 699-719.

Cheung, G., \& Lau, R. (2008) 'Testing mediation and suppression effects of latent variables: Bootstrapping with structural equation models', Organizational Research Methods, Vol. 11 No. 2, pp. 296-325.

Cummings, A., \& Oldham, G. (1997) 'Enhancing creativity: Managing work contexts for the high potential employee', California management review, Vol. 40 No. 1, pp. 22-38.

Davenport, T., \& Prusak, L. (1999) Working Knowledge, Harvard Business School Press, Cambridge.

Fong, L., \& Wu, C. (2007) 'The research of the relationships among employee job satisfaction, knowledge sharing and organization innovation capability', Journal of Technology Management, Vol. 12, pp. 1-34.

Fornell, C., \& Larcker, D. (1981) 'Evaluating Structural Equation Models with Unobservable Variables and Measurement Error', Journal of Marketing Research, Vol. 18 No. 1, pp. 39-50.

Ganesan, S., \& Weitz, S. (1996) 'The Impact of Staffing Policies on Retail Buyer Job Attitudes and Behaviors', Journal of Retailing, Vol. 72 No. 1, pp. 31-56.

Gögüş, G., Karakadılar, I., \& Apak, S. (2013) 'Innovation and Sustainable Growth Measurement in Hotel Industry: A Hierarchical Decision Making Model', Procedia Social and Behavioral Sciences, Vol. 9 No. 6, pp. 752-761.

Hansen, M. (1999) 'The Search-Transfer Problem: The Role of Weak Ties in Sharing Knowledge across Organization Subunits', Administrative Science Quarterly, Vol. 44 No. 1, pp. 82-111.

Harrison, N., \& Samaon, D. (2002) Technology Management: Text and International Cases, McGraw-Hill, New York.

Hendriks, P. (1999) 'Why share knowledge? The influence of ICT on the motivation for knowledge sharing', Knowledge and Process Management, Vol. 6 No. 2, pp. 91-100.

Hiltunen, E., \& Henttonen, K. (2016) '"I have ideas but I don't want to say them aloud." Employee-driven innovation discourses at a retail chain store', International Journal of Entrepreneurship and Innovation Management, Vol. 20 No. 5/6, pp. 349 $-359$.

Hollenstein, H. (1996) 'A composite indicator of a firm's innovativeness. An empirical analysis based on survey data for Swiss manufacturing', Research Policy, Vol. 25 No. 4, pp. 633-645. 
Holub, S. (2003) 'Knowledge sharing is a change-management exercise', Tax Practice Management, Vol. 34.

Hu, B., \& Zhao, Y. (2016) 'Creative Self-efficacy Mediates the Relationship Between Knowledge Sharing and Employee Innovation' Social Behavior and Personality: An International Journal, Vol. 44 No. 5, pp. 815-826.

Hu, L., \& Bentler, P. (1999) 'Cutoff criteria for fit indexes in covariance structure analysis: conventional criteria versus new alternatives', Web of Science, Vol. 6 No. 1, pp. 155.

Huhtala, H., \& Parzefall, M. (2007) 'A Review of Employee Well-Being and Innovativeness: An Opportunity for a Mutual Benefit', Creativity and Innovation Management, Vol. 16 No. 3, pp. 229-306.

Hurley, R., \& Hult, G. (1998) 'Innovation, Market Orientation, and Organizational Learning: An Integration and Empirical Examination', Journal of Marketing, Vol. 62 No. 3, pp. 42-54.

Hurt, H., Joseph, K., \& Cook, C. (1977) 'Scale for the measurement of innovativeness', Human Communication Research, Vol. 4 No. 1, pp. 58-65.

Imran, M., Ilyas, M., Aslam, U., \& Fatima, T. (2018) 'Knowledge processes and firm performance: the mediating effect of employee creativity', Journal of Organizational Change Management, Vol. 31 No. 3, pp. 512-531.

Ipe, M. (2003) 'Knowledge sharing on organizations: A conceptual framework', Human Resource Development Review, Vol. 2 No. 4, pp. 337-358.

Jaberi, E. (2016) 'The effect of knowledge sharing on innovative behavior among employee of Besat hospital in city of Hamedan', International Academic Journal of Accounting and Financial Management, Vol. 3 No. 4, pp. 41-47.

Jantunen, A. (2005) 'Knowledge-processing capabilities and innovative performance: an empirical study', European Journal of Innovation Management, Vol. 8 No. 3, pp. 336-349.

Kamasak, R., \& Bulutlar, F. (2010) 'The influence of knowledge sharing on innovation', Journal of European business review, Vol. 22 No. 3, pp. 306-317.

Kogut, B., \& Zander, U. (1992) 'Knowledge of the firm, combinative capabilities, and the replication of technology', Organization Science, Vol. 3 No. 3, pp. 383-397.

Kuo, Y., Kuo, T., \& Ho, L. (2014) 'Enabling innovative ability: knowledge sharing as a mediator', Industrial Management \& Data Systems, Vol. 114 No. 5, pp. 696-710.

Lawson, B., \& Samson, D. (2001) 'Developing Innovation Capability in Organizations: A Dynamic Capabilities Approach', International Journal of Innovation Management, Vol. 5 No. 3, pp. 377-400.

Lee, J. (2018) 'The Effects of Knowledge Sharing on Individual Creativity in Higher Education Institutions: Socio-Technical View', Administrative Sciences, Vol. 8 No. 21, pp. 1-16.

Letangule, S., \& Letting, N. (2012) 'Effect of Innovation Strategies on Performance of Firms in the Telecommunication Sector in Kenya', International Journal of Management \& Business Studies, Vol. 2 No. 3, pp. 75-78.

Liao, S., Fei, W., \& Chen, C. (2007) 'Knowledge sharing, absorptive capacity, and innovation capability: an empirical study of Taiwan's knowledge intensive industries', Journal of Information Science, Vol. 33 No. 3, pp. 1-20.

Lin, H. (2007) 'Knowledge sharing and firm innovation capability: an empirical study', International Journal of Manpower, Vol. 28 No. 3/4, pp. 315-332.

Lotz, M. (2018) 'Organising routines and spaces for employee-driven innovation in global work arrangements', International Journal of Entrepreneurship and Innovation Management, Vol. 22 No. 4/5, pp. 338 - 361.

Maimone, F., \& Sinclair, M. (2014) 'Dancing in the dark: creativity, knowledge creation and (emergent) organizational change', Journal of Organizational Change Management, Vol. 27 No. 2, pp. 344-361.

Maryville, S. (1992) 'Entrepreneurship in the Business Curriculum', Journal of Education for Business, Vol. 68 No. 1, pp. 27-31.

Mayers, L., Gamst, G., \& Guarino, A. (2012) Applied Multivariate Research, SAGE Publications, New York. 
Nonaka, I., \& Takeuchi, H. (1995) The knowledge creating company: How Japanese companies create the dynamics of innovation, Oxford University Press, New York.

Norris, M., \& Lecavalier, L. (2009) 'Evaluating the Use of Exploratory Factor Analysis in Developmental Disability Psychological Research', Journal of Autism and Development Disorders, Vol. 40 No. 1, pp. 8-20.

Nunnally, J. (1978) Psychometric theory, McGraw-Hill, New York.

Ologbo, A. (2015) 'The Influence of Knowledge Sharing on Employee Innovation Capabilities', International Journal of Human Resource Studies, Vol. 5 No. 3, pp. 102-110.

Onishi, T. (2019) Vietnam's top telecom to adopt 'self-developed' 5G tech, Nikkei Asian Review.

Peterson, R. (1994) 'A Meta-Analysis of Cronbach's Coefficient Alpha', Journal of Consumer Research, Vol. 21 No. 2, pp. 381-391.

Plessis, M. (2007) 'The role of knowledge management in innovation', Journal of Knowledge Management, Vol 11 No. 4, pp. 20-29.

Podrug, N., Filipovic, D., \& Kovac, M. (2017) 'Knowledge sharing and firm innovation capability in Croatian ICT companies', International Journal of Manpower, Vol. 38 No. 4, pp. 632-644.

Rahab, Sulistyandari, \& Sudjono. (2011) 'The development of innovation capability of small medium enterprises through knowledge sharing process: An empirical study of Indonesian creative industry', International Journal of Business and Social Sciences, Vol. 2 No. 21, pp. 112-123.

Rajapathirana, R., \& Hui, Y. (2018) 'Relationship between innovation capability, innovation type, and firm performance', Journal of Innovation \& Knowledge, Vol. 3 No. 1, pp. 44-55.

Raykov, M. (2014) 'Employer support for innovative work and employees' job satisfaction and job-related stress', Journal of occupational health, Vol. 56 No. 4, pp. 244-251.

Sarstedt, M., Ringle, C., Cheah, J., Ting, H., Moisescu, O., \& Radomir, L. (2019). Structural model robustness checks in PLS-SEM. Tourism Economics, 1-24.

Saunila, M., \& Ukko, J. (2014) 'Intangible aspects of innovation capability in SMEs: Impacts of size and industry', Journal of Engineering and Technology Management, Vol. 33, pp. 32-46.

Slater, S. (1995) 'Issues in Conducting Marketing Strategy Research', Journal of Strategic Marketing, Vol. 3 No. 4, pp. 257-270.

Slater, S., Mohr, J., \& Sengupta, S. (2014) 'Radical Product Innovation Capability: Literature Review, Synthesis, and Illustrative Research Propositions', The Journal of Production Innovation Management, Vol. 31 No. 3, pp. 552-566.

Song, Z., Fan, L., \& Chen, S. (2008) 'Knowledge sharing and innovation capability: Does absorptive capacity function as a mediator?'. Paper presented at the International Conference on Management Science and Engineering. IEEE, California.

Svensson, G., Ferro, C., Høgevold, N., Padin, C., Varela, J., \& Sarstedt, M. (2018). Framing the triple bottom line approach: Direct and mediation effects between economic, social and environmental elements. Journal of Cleaner Production, 197(1), 972991.

Tassabehji , R., Mishra, J., \& Dominguez-Péry, C. (2019) 'Knowledge sharing for innovation performance improvement in micro/SMEs: an insight from the creative sector', Production Planning \& Control, Vol. 30 No. 10-12, pp. 935-950.

Van Den Hooff, B., \& De Ridder, J. (2004) 'Knowledge Sharing In Context: The Influence of Organizational Commitment, Communication Climate and CMC Usage on Knowledge Sharing', Journal of Knowledge Management, Vol. 8 No. 6, pp. 117-130.

Verde, M., De Castro, G., \& Lopez, J. (2011) 'Organizational knowledge assets and innovation capability. Evidence from Spanish manufacturing firms', Journal of Intellectual Capital, Vol. 12 No. 1, pp. 5-19.

VNPT. (2017) VNPT wishes to cooperate with the Startup, Vietnam Posts and Telecommunications Group. 
Wang, C., \& Hu, Q. (2017) 'Knowledge sharing in supply chain networks: Effects of collaborative innovation activities and capability on innovation performance', Technovation. doi:10.1016/j.technovation.2017.12.002

Wang, Z., \& Wang, N. (2012) 'Knowledge sharing, innovation and firm performance', Expert Systems with Applications, Vol. 39 No. 10, pp. 8899-8908.

Wang, Z., \& Wang, N. (2012) 'Knowledge sharing, innovation and firm performance', Expert Systems with Applications, Vol. 39 No. 10, pp. 8899-8908.

Yeşil, S., Koska, A., \& Büyükbeşe, T. (2013) 'Knowledge Sharing Process, Innovation Capability and Innovation Performance: An Empirical Study', Procedia - Social and Behavioral Sciences, Vol. 75 No. 3, pp. 217-225.

$\mathrm{Yu}, \mathrm{C} ., \mathrm{Yu}, \mathrm{T} ., \mathrm{Yu}, \mathrm{C}$. (2013) 'Knowledge sharing, organizational climate, and innovative behavior: a cross-level analysis of effects', Social Behavior and Personality, Vol. 41 No. 1, pp. 143-156.

Yuan, F., \& Woodman, R. (2010) 'Innovative behavior in the workplace: the role of performance and image outcome expectations', Academy of Management Journal, Vol. 53 No. 2, pp. 323-342. 